Southern Illinois University Carbondale OpenSIUC

Publications

Department of Geography and Environmental

Resources

6-1998

\title{
Taking a Pragmatic Behavioral Approach to Alternative Agriculture Research
}

Leslie Duram

Southern Illinois University Carbondale, duram@siu.edu

Follow this and additional works at: http:// opensiuc.lib.siu.edu/gers_pubs

Published in American Journal of Alternative Agriculture, Vol. 13 No. 2 (June 1998) at doi: 10.1017/ S0889189300007724

\section{Recommended Citation}

Duram, Leslie. "Taking a Pragmatic Behavioral Approach to Alternative Agriculture Research." (Jun 1998).

This Article is brought to you for free and open access by the Department of Geography and Environmental Resources at OpenSIUC. It has been accepted for inclusion in Publications by an authorized administrator of OpenSIUC. For more information, please contact opensiuc@lib.siu.edu. 


\section{Taking a pragmatic behavioral approach to alternative agriculture research}

\section{Leslie Aileen Duram}

Abstract. This article seeks to stimulate thought on the philosophy behind agricultural research. Pragmatism is identified as a philosophical basis for studying environmental issues that focus on human behavior. The ways in which this approach is applicable to the study of alternative agriculture are illuminated. "Behavioral pragmatists" differ from "behavioral positivists" in their aim, focus, process, and approach to research. I describe the main goals of the pragmatic behavioral approach: accepting a systems approach to study the interrelationships between humans and the environment; gaining understanding through human experiences; viewing problems as whole complex "problematic situations"; and promoting social activism and appropriate policy formulation. Combining qualitative and quantitative methods is often most effective. Pragmatism allows for holistic analysis that incorporates numerous factors that influence human uses of the environment. A specific example shows how behavioral pragmatism is effective in research on alternative agriculture.

Key words: pragmatism, behavioral research

Human impacts on the environment are often studied primarily as either "social" or "ecological" because most researchers frame their questions in this segregated manner. Within agricultural land use, for example, lines are often drawn between social and ecological research. This division is widened by the traditional paradigm split between natural and social sciences, an enduring obstacle to integrative research (Blaikie, 1985).

Efforts to integrate the physical and social aspects of environmental studies are needed, as are new research paradigms that incorporate aspects of both positivism and pragmatism. Positivism draws on the scientific method and empirical methods of research, while pragmatism is based on understanding human experience. Alternative agriculture is a specific area in which to develop these ideas. Agriculture is a productive enterprise, an extractive activ-

Leslie Aileen Duram is Assistant Professor, Department of Geography, Southern Illinois University, Carbondale, IL 62901-4514; duram@ @iu.edu. ity, and a way of life based on one of the most integrated relationships between humans and their environment. Of the many human activities that affect nature, agriculture has been the most pervasive cause of large-scale biophysical change of the landscape (Jackson, 1980; Bennett and Dahlberg, 1990). Both social and ecological factors are pervasive in agricultural decision making, and thus must be studied in an interrelated way.

Human and physical aspects of agriculture can be integrated through individual farmers' environmental perceptions and associated land use decisions that influence and are influenced by the natural environment. Behavioral research illuminates individual characteristics (e.g., attitudes, knowledge, experience, behavior) that describe people's decisions and how they affect the local environment. When used toward pragmatic ends, such research can stimulate social activism and policy initiatives that encourage ecologically sustainable land use decisions.

\section{Studying People's Behavior}

Behavioral approaches emerged in the 1960s out of a dissatisfaction with the positivists' methods and normative models. Early behavioral research, however, did not sever its ties with the previous paradigm. Wolpert (1964), for example, employed descriptive behavioral theory to explain farmer decision making in Sweden, but remained very much within the positivist paradigm. He statistically compared all farmers' choices to a "rational" model in which high productivity and high income were the ultimate goals. He explained lower productivity and income solely as a sign of farmer "maladjustment" (Wolpert, 1964, p. 557). Although the positivist approach would have remained appropriate for his research design, he chose a partially behavioral approach, yet omitted personal factors and concepts of stewardship, which are important in explaining agricultural behavior.

More recently, behavioral approaches have widened the scope of social sciences by emphasizing the value of understanding individuals in addition to ecological, political and social structures. But regardless of the original reason for its development, much behavioral research remains within a positivist paradigm. People are still commonly placed in "neat" boxes when they respond to survey questions. Researchers still begin with a preconceived theory and seek to prove their hypothesis, even though human decision making is complex and affected by numerous influences. The commonly accepted notion of a "random stratified sample," for example, is valueladen and creates analysis determined by categories that are established in advance by the researcher. The categories could 
omit important aggregate groups, who would then be excluded from the analysis and results.

One subfield of environmental research is associated with the work of Gilbert F. White and his students. This field, often termed "natural hazards," encompasses a broad range of natural resource and environmental studies. This research is distinct from other behavioral approaches because of its philosophical basis, which is drawn from the pragmatic tradition. Pragmatism is concerned with understanding and resolving problems that occur in our uncertain world. Thus pragmatists acknowledge that their inquiry will not lead to certainty because nothing in the world is certain. According to William James, a central figure in this philosophy, a pragmatist "turns away from abstraction and insufficiency, from verbal solutions, from bad a priori reasons, from fixed principles, closed systems, and ... the pretense of finality in truth" (James, 1907, p. 51). Instead, a pragmatist "defines meaning and knowledge in terms of their function in experience" (Beck, 1969, p. 515). An underlying pragmatic concern among some behavioral researchers is the importance of dealing with problems in the real world.

\section{Pragmatists and Positivists}

While a behavioral approach has potentially broad appeal in natural resource management, land use, and human impact studies, it has left many scholars and students searching for a theoretical basis (Boal and Livingstone, 1989; Emel and Peet, 1991). As a participant in this theoretical exploration, I have discovered that there are at least two distinct realms of behavioral research. In the following, I describe "behavioral positivism" and "behavioral pragmatism." I contrast these two approaches in order to clarify their philosophical bases, but there clearly is potential for merging and overlapping them.

Both behavioral pragmatism and behavioral positivism evolved out of dissatisfaction with positivist approaches, but their focus, process, and aims differ (Table 1). First, behavioral positivists conduct more theoretical, abstract studies (Golledge, 1981, p. 328). Behavioral pragmatists, on the other hand, believe that research should be used as a means of

Table 1. Differences between two types of behavioral research

\begin{tabular}{|c|c|c|}
\hline \multirow{2}{*}{$\begin{array}{l}\text { Contrast } \\
\text { Area }\end{array}$} & \multicolumn{2}{|c|}{$\begin{array}{l}\text { Behavioral Research } \\
\text { (focus on individuals) }\end{array}$} \\
\hline & Behavioral Positivism & Behavioral Pragmatism \\
\hline Philosophy & no single philosophy & pragmatism basis \\
\hline Focus & abstract; varies & actual human problems \\
\hline Approach & hypothesis testing on certain topic & $\begin{array}{l}\text { problematic situation } \\
\text { leads to questions }\end{array}$ \\
\hline Process & $\begin{array}{l}\text { deductive } \\
\text { theory } \rightarrow \text { hypotheses } \rightarrow \text { problems }\end{array}$ & $\begin{array}{l}\text { inductive } \\
\text { problem } \rightarrow \text { theory }\end{array}$ \\
\hline Aims & $\begin{array}{l}\text { seek "objective" research } \\
\text { build theories; models }\end{array}$ & $\begin{array}{l}\text { seek understanding } \\
\text { improve policies }\end{array}$ \\
\hline
\end{tabular}

problem solving and for the promotion of human welfare (Frazier, 1981). Many behavioral pragmatists would agree with the opinion of Gilbert F. White (1972, p. 103):

I feel strongly that I should not go into research unless it promises results that would advance the aims of the people affected and unless I am prepared to take all practicable steps to help translate the results into action.

This statement indicates the extent to which pragmatists aim to conduct research whose results are easily translated into practical—often policy oriented-ends. Academic research can be constrained by oppressive objectivity, which leads to the separation of much research from practical policy suggestions. The aim of behavioral pragmatism, however, is to understand the multiple factors involved in people's actions in a given situation (Castle, 1996). Environmental topics are particularly conducive to such applied goals, because natural resource management, environmental policy, and agricultural land use invite practical action.

Behavioral pragmatists focus on an individual decision maker within an actual natural resource situation. The problem, issue, or conflict is perceived in its broad context. This leads to research inquiry in an attempt to better understand and ultimately solve a human problem, which can result in policy or social change. Behavioral positivists, on the other hand, study individuals in various settings, seeking to create an objective model to explain a given topic. The positivists are thus deductive, moving from theory to the development of hypotheses in order to study a specific problem, while pragmatists are inductive, moving from a complex problem to a general theory of understanding in order to improve a given situation.

\section{Pragmatic Research Goals}

I will describe four pragmatic behavioral goals that can guide researchers: 1 ) accepting chaos in the interrelationship between humans and the environment; 2) seeking an understanding based on human experience; 3) viewing a problem as a complex problematic situation; and 4) promoting activism and policy formulation. These goals are built upon notions developed by Light and Katz (1996) and by Wescoat $(1987 ; 1992)$, who described pragmatism in environmental research and geography. After outlining these pragmatic behavioral goals, I will specifically describe their applicability to the study of alternative agriculture.

First, society and nature are interdependent, and nature provides uncertainty that people define and attempt to resolve. Pragmatism accepts this notion of the precariousness of nature and assumes it is a real feature of every situation, according to pragmatist John Dewey (1958). To address current ecological problems, which often are an outcome of our attempts to control nature, pragmatism accepts the premise that nature is basically unpredictable. Chaos, according to Gleick (1987) is the irregular, discontinuous and erratic side of nature. Just as physical scientists question the suitability of linear prediction formulas for weather forecasting (Lorenz, 
1984), social scientists theorize that interactions between society and the environment have a chaotic relationship (Merchant, 1992). Behavioral pragmatism allows for such views by accepting a systems approach to our individual and societal relationships with nature. This provides research freedom, since pragmatism does not require a narrow investigation that seeks one resultant "truth."

A second goal of the pragmatic behavioral approach is to embrace human experience as a fundamental link in environmental decision making. According to Dewey, experience is what we do, how we learn, and what happens to us (Dewey, 1958; Thayer, 1970). Pragmatist Charles Peirce noted that we should look at general long-term effects and experiences, not just short-term specific ones (Harshorne and Weiss, 1931). Further, knowledge is valued for its usefulness, and understanding of a situation must be gained through one's own experiences or inferred from other people's experiences (Charon, 1979). Pragmatism focuses on tangible human situations, as opposed to abstractions. By investigating human behavior, we actually attempt to understand human experiences. Thus pragmatic inquiry is only instrumental, not an end in itself. The research aim is not to seek an absolute truth (because none exists), but to formulate policies and to aid in improving society. Abstract questions are asked only if they are directly relevant to a specific research case. Pragmatic behavioral research involves the study of human experience to understand the "truth" of what works best in a given situation.

Third, pragmatists seek to improve problematic situations rather than testing narrow research hypotheses removed from their contexts. Pragmatic behavioral research views an environmental problem not as an isolated event, but rather in its full context. This problematic situation is investigated through "decision elements" (e.g., social, technological, ecological, economic, perception, and spatial factors) that can be explored concurrently and interactively. This is linked to the "range of choice" concept commonly described in natural resource decision making (White, 1961). There is no fixed progression, and new elements may be discovered to define the problem better. Qualitative techniques are complementary to quantitative methods and are effective in searching out the complexity of human behavior (Miles and Huberman, 1994). A pragmatic researcher seeks to transform a problem by investigating its complex interrelated elements to understand the entire situation better. The goal is to present alternatives and to take appropriate action. This should lead to social activism and appropriate policies.

Many problems, and thus many research questions, are firmly embedded in our society, so the pragmatic aim of transforming a problematic situation often confronts the status quo. Pragmatic approaches acknowledge that scholars may need to confront "entrenched social constraints" (Wescoat, 1992, p. 596). This leads to the fourth goal: to contribute a unique perspective that links individual decision making to societal change through public participation. Academic inquiry can inform public choice, if research is practical and applied to issues in the real world. A pragmatic behavioral approach can provide a link to radical environmental philosophies (e.g., ecofeminism, deep ecology, the Greens) through an emphasis on individual decision makers at a grassroots level acting to promote environmental policies and social change. Behavioral pragmatists do not stress class, gender, or race differences, but rather seek to encourage each individual to be informed and take part in a truly democratic process. Indeed, pragmatists like Dewey stress that our democratic society requires diversity and a complex understanding of the world (Alexander, 1995). Pragmatic behavioral research seeks to understand and reinforce individual people's capacities for action. Individual and community empowerment can improve a problematic situation and eventually can lead to an improved society.

\section{Behavioral Pragmatism in Agriculture}

While few deny the productive strengths of the current U.S. farming system, its ecological and social dimensions are increasingly criticized. We must question the sustainability of industrial agricultural techniques manifest in the degradation of water quality, soil fertility, and ecosystem processes (Hallberg, 1987; Soule and Piper, 1992; Zaring, 1996). Social concerns are raised by those who believe that an agricultural system with many small family farms is more socially sustainable than one with fewer but larger agribusiness operations (Berry, 1986; Goering et al., 1993; Smolik et al., 1995). Others fear for worker safety and the safety of a food supply produced with toxic synthetic chemicals (Clancy, 1990; Jacobson et al., 1991; McDuffie et al., 1995).

Arguments from these perspectives reveal a broad problematic situation-the unsustainability of industrialized agriculture. Pragmatism sets the stage for an inclusive view of the situation, and raises questions that integrate ecological and social concerns: What might U.S. agriculture look like in the future? What changes are now occurring in the relationships between people and the land? Attempts to answer these questions may fall within behavioral research, and a pragmatic behavioral approach would broaden the questions to understand real world agricultural decision making.

The four goals of pragmatic behavioral research are particularly applicable to agricultural research. Farming is tied to our perceptions of and ability to work within the natural system. The pragmatic behavioral approach accepts chaos and uncertainty in nature and seeks to expand the scope for human adjustment. Thus, notions of sustainable development and questions of short-term versus long-term interaction with nature can be encompassed fully. For example, the use of pesticides may control pests for the short run, but can lead to long-term problems, including pest tolerance and nonpointsource water pollution. Pragmatism acknowledges that long-term control over the environment is not possible because human and physical systems are constantly in flux and their interrelationship is based on delicate balances within a dynamic system. Humans must adjust and develop a sustainable relationship with nature. The pragmatic behavioral approach does not seek judgment; rather, it seeks to learn what has occurred already, what is happening now, and what adjustments are possible. 
Individual farmers' experiences provide insight into the current agricultural system. Without investigating these experiences, we can obtain only cursory information. But we must seek to investigate farmers' characteristics and decision making fully, rather than employing survey methods that place farmers into specific categories from the outset. Qualitative techniques are complementary to quantitative methods and are effective in discovering a fuller, richer view of farmers' everyday actions (Miles and Huberman, 1994). Pragmatic inquiry within an agricultural context encourages deep questioning of our current system of industrial agricultural production. Critics question the sustainability of industrial agriculture. Understanding farmers' characteristics and attitudes associated with the adoption of conservation methods will identify the actual course of action taken by some farmers. This would lead to a better understanding of the system-wide transition toward sustainable agriculture, which could help in creating appropriate agricultural policies. Historically, the U.S. has drawn on the importance of individual family farms and a populist movement based on rural ideals (Kloppenberg and Geisler, 1985; Nash, 1990). However, much current agricultural research has assumed that a viable production system must be based on large-scale industrial farming. Pragmatic behavioral research can address the complex problems caused by clashes between historical ideals and the current agricultural system.

\section{A Pragmatic Behavioral Study: The Adoption of Alternative Agriculture}

While policy and research often support the conventional agricultural system at the expense of alternatives, the pragmatic behavioral approach encourages the study of true alternatives, such as organic farming, permaculture, and cooperative community-based agriculture. Alternative agriculture is a link between individuals, society, and the environment.

The "experimental method," according to Dewey, is a pragmatic means of incorporating flexible and pluralistic methods that best fit a specific research subject (Alexander, 1991). I present a brief overview of methods and results of a pragmatic behavioral study I conducted in Colorado in 1994 (Duram, 1997). The study began with recognition of a problematic situation-the unsustainability of U.S. agriculture. Relevant questions emerged, including: What factors influence farmers who adopt alternative methods? Who are these farmers? How do they make the transition to alternative agriculture?

A survey of nearly 150 farmers was conducted to investigate operational characteristics, demographic variables, decision-making factors, and attitudes on ecology, technology, scale of production, and agricultural idealism. I analyzed data obtained from mail questionnaires from more industrial and more alternative farmers. Univariate quantitative analysis provided a cursory definition of several groups of farmers. I also conducted in-depth, multiday interviews of case study farmers; qualitative analysis of interview data revealed deeper motivations behind farmers' decisions to adopt alternative methods.

The questionnaires and interviews were philosophically based on the four goals of pragmatism. First, the pragmatic acceptance of chaos in nature involved investigation into farmers' perceptions of risk and their relationship to the environment. I discovered that certain characteristics were present, to varying degrees, among the farmers. These included personal and perceptual factors such as: seeking challenges, acceptance of risk, openness to outsiders and new ideas, trust in one's own farming experience, and feeling in control of one's own operation. Operational factors also dealt with the acceptance of chaos: cropping diversity, participation in government programs, and marketing strategies. Although each farmer is unique, a pragmatic analysis helps me understand how these characteristics differ between groups of industrial and alternative farmers.

Second, the study considered how farmers draw from their experiences and those of other farmers to make informed decisions. In conversational interviews with farmers, it was obvious that multiple factors influence their decision to adopt or reject alternative methods. These subtle and varying traits might not have been discovered if narrow positivist methods had been employed. Third, I investigated the problematic situation (i.e., agricultural sustainability) through an understanding of farmers' individual solutions and adaptations. Farmers shared their experiences and described their personal attempts at rectifying the problems they perceived. Their actions included the adoption of chemical-free agriculture, soil conservation methods, social activism, and numerous other actions.

Fourth, I addressed the notion of activism and policy change by investigating how individual farmers independently gather information, decide to adopt alternative methods, and seek alternative marketing and distribution channels. This information could assist agency personnel in identifying appropriate educational and policy initiatives to reach farmers. Further, in alternative production, individual farmers overcome ingrained social structures by confronting generational values, identifying unconventional markets, and seeking alternative sources of information. The pragmatic behavioral approach seeks to understand and reinforce individuals' capacities to take action, so my research viewed individuals as the necessary component for change in U.S. agriculture.

This example of alternative agriculture is just one application of a pragmatic behavioral approach. Numerous environmental topics provide rich problematic situations for study (e.g., local environmental activism, land use policies, attitudes about rural sustainability, public lands conflicts).

\section{Conclusions}

A pragmatic behavioral approach can jointly address environmental and social perspectives that allow us to investigate human experience, human adjustment to natural processes, and the subsequent range of choice that individuals and society identify. Pragmatic researchers should speak publicly to raise concerns, inform people, and encourage cooperation. In addition, this approach is particularly valuable at a grassroots level for encouraging ideas and movements regarded as outside the mainstream.

For more researchers to employ behavioral pragmatism, it must be recognized as a valid philosophical approach for the 
social sciences. Most adherents to this approach prefer to spend their time on applied research projects that deal with human problems, rather than partaking in debates on philosophical/theoretical concerns. This may explain why behavioral pragmatism has not been embraced in the social sciences. Researchers should be aware of and use a pragmatic behavioral approach to address complex environmental issues.

Acknowledgment. I thank W. Riebsame, J. Wescoat, P. Stowkowski, G.F. White, T. Alexander, R. Roberts, and several anonymous reviewers for their direct and indirect guidance in this research.

\section{References}

1. Alexander, T. 1991. The technology of desire: John Dewey, social criticism, and the aesthetics of human existence. In P. Durbin (ed). Europe, America, and Technology: Philosophical Perspectives. Kluwer, Amsterdam. pp. 109-126.

2. Alexander, T. 1995. Educating the democratic heart: Pluralism, traditions and the humanities. Studies in Philosophy and Education 12:245259.

3. Beck, R.N. 1969. Perspectives in Philosophy. Holt, Rinehart \& Winston, New York, N.Y.

4. Bennett, J.W., and K.A. Dahlberg. 1990. Institutions, social organization, and cultural values. In B. Turner, W. Clark, R. Kates, J. Richards, J. Mathews, and W. Meyer (eds). The Earth as Transformed by Human Action: Global and Regional Changes in the Biosphere over the Past 300 Years. Cambridge University Press, New York, N.Y. pp. 69-86.

5. Berry, W. 1986. The Unsettling of America: Culture and Agriculture. Sierra Club, San Francisco, California.

6. Blaikie, P. 1985. Political Ecology of Soil Erosion in Developing Countries. Longman, New York, N.Y.

7. Boal, F.W., and D. Livingstone, eds. 1989. The Behavioural Environment: Essays in Reflection, Application, and Reevaluation. Routledge, London, England.
8. Castle, E. 1996. A pluralistic, pragmatic and evolutionary approach to natural resource management. In A. Light and E. Katz (eds). Environmental Pragmatism. Routledge, London, England. pp. 231-250.

9. Charon, J.M. 1979. Symbolic Interactionism. Prentice Hall, New York, N.Y.

10. Clancy, K. 1990. Agriculture and human health. In C. Edwards, R. Lal, P. Madden, R. Miller, and G. House (eds). Sustainable Agricultural Systems. Soil and Water Conservation Society, Ankeny, Iowa. pp. 655-665.

11. Dewey, J. 1958. Experience and Nature. Dover, New York, N.Y.

12. Duram, L. 1997. A pragmatic study of conventional and alternative farmers in Colorado. Professional Geographer 49(2):202-213.

13. Emel, J., and R. Peet. 1991. Resource management and natural hazards. In R. Peet and N. Thrift (eds). New Models in Geography: The Political Perspective. Unwin and Hyman, Boston, Massachusetts. pp. 49-76.

14. Frazier, J. 1981. Pragmatism: Geography and the real world. In M. Harvey and B. Holly (eds). Themes in Geographic Thought. Croom Helm, London, England. pp. 61-72.

15. Gleick, J. 1987. Chaos: The Making of a New Science. Viking, New York, N.Y.

16. Goering, P., H. Norberg-Hodge, and J. Page. 1993. From the Ground Up: Rethinking Industrial Agriculture. Zed Books, London, England.

17. Golledge, R. G. 1981. Misconceptions, misinterpretations, and misrepresentations of behavioural approaches in human geography. Environment and Planning A 13:1325-1344.

18. Hallberg, G. 1987. Agricultural chemicals in ground water: Extent and implications. Amer. J. Alternative Agric. 2:3-15.

19. Harshorne, C., and P. Weiss. 1931. Collected Papers of Charles Sanders Peirce. Vol. 5. Harvard Univ. Press, Cambridge, Massachusetts.

20. Jacobson, M.F., L.Y. Lefferts, and A.W. Garland. 1991. Safe Food:
Eating Wisely in a Risky World. Living Planet Press, Los Angeles, California.

21. Jackson, W. 1980. New Roots for Agriculture. Univ. of Nebraska Press, Lincoln.

22. James, W. 1907. Pragmatism: A New Name for Some Old Ways of Thinking. Longman \& Green, New York, N.Y.

23. Kloppenberg, J., and C. Geisler. 1985. The agricultural ladder: Agrarian ideology and the changing structure of U.S. agriculture. J. Rural Studies 1:59-72.

24. Light, A., and E. Katz (eds). 1996. Environmental Pragmatism. Routledge, London, England.

25. Lorenz, E. 1984. Predictability: Does the flap of a butterfly's wings in Brazil set off a tornado in Texas? Tellus 36A:98-110.

26. McDuffie, H., J. Dosman, K. Semchuk, S. Olenchock, and A. Senthilselvan. 1995. Agricultural Health and Safety: Workplace, Environment, Sustainability. Lewis, New York, N.Y.

27. Merchant, C. 1992. Radical Ecology: The Search for a Livable World. Routledge, New York, N.Y.

28. Miles, M., and A. Huberman. 1994. Qualitative Data Analysis. Sage, Thousand Oaks, California.

29. Nash, R. 1990. American Environmentalism: Readings in Conservation History. 3rd ed. McGraw-Hill, New York, N.Y.

30. Smolik, J., T. Dobbs, and D. Rickerl. 1995. The relative sustainability of alternative, conventional, and reducedtill farming systems. Amer. J. Alternative Agric. 10:25-34.

31. Soule, J.D., and J.K. Piper. 1992. Farming in Nature's Image: An Ecological Approach to Agriculture. Island Press, Washington, D.C.

32. Thayer, H.S. 1970. Pragmatism: The Classic Writings. New American Library, New York, N.Y.

33. Wescoat, J.L. 1987. The "practical range of choice" in water resources geography. Progress in Human Geography 11:41-59.

34. Wescoat, J.L. 1992. Common themes in the work of Gilbert White and John 
Dewey: A pragmatic appraisal. Annals Assoc. American Geographers 82:587-607.

35. White, G.F. 1961. The choice of use in resources management. Natural Resources J. 10: 20-40.
36. White, G.F. 1972. Geography and public policy. Professional Geographer 24(2):101-104.

37. Wolpert, J. 1964. The decision process in spatial context. Annals Assoc. American Geographers 54:537-558.
38. Zaring, D. 1996. Federal legislative solutions to agricultural nonpoint source pollution. Environmental Law Review 26:10128-10137.

\section{USDA Abandons Three Contentious Issues in Proposed Organic Standards}

Responding to 200,000 "extraordinary" public comments, the USDA abandoned its proposal to include the products of genetic engineering, irradiation, and municipal sewage sludge in organic food production, which had been part of the national organic standards the agency proposed late last year. "USDA is committed to developing national organic standards that organic farmers and consumer will embrace," said USDA Secretary Dan Glickman. "Thousands of commenters requested that USDA issue revised proposed standards, and we intend to do so. The revised proposal will contain fundamental changes from our initial draft."

According to Newsweek (June 1, 1998), "The USDA yanked the proposal back for a rewrite after it took an unprecedented public beating. Some 200,000 people wrote, faxed, e-mailed or spoke up at public hearings to let the USDA know they overwhelmingly rejected the standards, especially if they allowed what became known as the Big Three to be sold as organic: genetically engineered food, irradiated food and food grown in municipal sewage sludge."

USDA also said that many of the public comments asserted that national organic standards must be rigorous and credible. Otherwise, commenters expressed concern that consumers will lose faith in the organic label. "If organic farmers and consumers reject our national standards, we have failed," Glickman said. USDA will evaluate the public comments on the initial proposal and publish the revised proposal later this year.

Newsweek's three-page article asks, "Is there any reason at all to pay extra for organic? Sure....A USDA report documents numerous examples of the environmental threat posed by farm chemi cals, including the destruction of fish, wildlife and beneficial insects. Farm workers who apply pesticides and herbicides have disproportionately high rates of some cancers -- and so do their children." From an environmental point of view, "the lower price tag on conventional produce may be deceptive," according to the article, which argues that "our food supply only seems cheap because its real costs aren't represented by supermarket bar codes." Once the final USDA regulations are in place, by about 2000 , "shoppers who choose organic will know for the first time exactly what they're buying."

According to comprehensive public comments filed by the Wallace Institute, the proposed national organic standards were "fatally flawed" and "must change substantially." The Institute's comments covered every aspect of the proposed standards for the national organic program and filled 125 pages. Among the key points made in the comments were:

- The program should better reflect a public-private partnership by providing more authority to existing state and private certification organizations.

- The proposal disregards the authority granted to the National Organic Standards Board (NOSB) to determine the materials that may be placed on the National List of allowable synthetics in organic production. The Institute's comments advise the USDA to uphold that authority, a view reflected in a legal memorandum written by the Wallace Institute and submitted as an official NOSB document to the USDA Secretary, which provides a solid legal argument for upholding the Board's authority to determine the National List.

- The USDA should delete its proposed addition of genetically engineered organisms, ionizing radiation, and bio solids as acceptable materials, and follow the NOSB recommendations severely limiting the use of National List materials.

- The program should include a progressive fee structure that takes into account the size of farm, handling, and certification operations. The proposal does not account for differences in the size of farms or certification agents.

- The proposed rules on livestock fail to meet international standards or industry expectations. The Institute recommended revisiting every component of the livestock proposal.

- The proposed prohibition on ecolabeling should be deleted; the USDA should defer eco-labeling concerns to the Federal Trade Commission, which has been monitoring the issue.

As the next step, the Wallace Institute recommended submitting a re-proposal to the Federal Register by October 1, 1998, to allow sufficient time for USDA staff to analyze the public comments and make necessary adjustments. It also recommended a comment period on the reproposal of at least 90 days, which would allow final rules to be published in the Federal Register in the spring of 1999 , with a goal of final implementation in the growing season of 2000 . Rewriting the proposal should not be overwhelming and would lead to popular support, if the new rules reflect the NOSB recommendations, the Institute wrote.

"Everyone understands the headlines about the proposal, so now let's roll up our sleeves and get to work on the details so we can have a program in place by 2000," said Kathleen Merrigan, the Wallace Institute's Senior Analyst and a member of the National Organic Standards Board. "The vast majority of public comments urged the Secretary to adopt the NOSB recommendations." 


\section{UPCOMING EVENTS}

July 23, Milan No-Till Crop Production Field Day and Research Tours will be held in Milan, TN; contact Dr. Blake Brown, Milan Experiment Station, 6505 Ellington Drive, Milan, TN 38358; (901) 686-7362; e-mail utmilan@usit.net

July 29, "Tools for Transitioning" Field Day will be held in Holtwood, PA; contact Steve Groff, Cedar Meadow Farm, 679 Hilldale Road, Holtwood, PA 17523; (717) 284-5152; e-mail sgroff@epix.net; information is available on the Internet at http://www.cedarmeadowfarm.com

August 13-21, "Permaculture Fundamentals for Women" will be held at Culture's Edge, 1025 Camp Elliott Road, Black Mountain, N.C. 28711; (828) 298-2399; e-mail culturesedge.earthaven.org
August 5-9, "Beyond Politics: Rethinking the Future of Democracy," the 61st Annual Meeting of the Rural Sociological Society, will be held in Portland, OR; contact JoAnn Jaffe, Program Chair, Dept. of Sociology/Social Studies, University of Regina, Regina, SK S4S 0A2, Canada; (306) 585-4198; e-mail joann.jaffe@uregina.ca

August 7-9, 24th Northeast Organic Farming Association Summer Conference will be held in Amherst, MA; contact NOFA, 411 Sheldon Road, Barre, MA 01005; (978) 3552853.

August 10-14, "Ecology and Design: Northeastern Landscapes," and August 21-23, "Selecting a Native Plant Palette: Using Native Plants in Public and Private Landscapes" will be held at Conway School of Landscape Design, P.O. Box 179, Conway, MA 01341; (413) 369-4044; e-mail workshops@csld.edu

August 14-16, "HerbFest'98" will be held in Norway, IA; contact HerbFest '98, P.O. Box 299, Norway, IA 52318; 1-800-669-3275.

September 9-10, "It's Just Common Sense: Practical Approaches to Better Groundwater Management," the 14th Annual Groundwater Foundation Fall Symposium, will be held in San Antonio, TX; contact the Groundwater Foundation, P.O. Box 22558, Lincoln, NE 68542; e-mail susan@groundwater.org

September 10, Thompson On-Farm Research Field Day will be held at the Thompson Farm, Boone, IA; contact Dick and Sharon Thompson, 2035 190th St., Boone, IA 50036; (515) 432-1560.

\section{RESOURCES}

"Agroforestry: Agriculture and Forestry Working Together," a 59-minute video, is available on loan from the National Agroforestry Center, USDA FS/NRCS, East CampusUNL, Lincoln, NE 68583-0822; (402) 4375178; on the Internet, http://www.unl.edu/nac

"Food Production And Environmental Stewardship: Examples of How Food Companies Work With Growers" is available from Richard Kashmanian; Office of Policy Development; Office of Policy, Planning, and Evaluation (2128); U.S. EPA, 401 M St., SW, Washington, D.C. 20460; e-mail kashmanian.richard@epamail.epa.gov

"Investing in the Future of Agriculture: The Massachusetts Farmland Protection Program and the Permanence Syndrome" is \$14.95 plus shipping/handling from American Farmland Trust at 1-800-370-4879.

"Growing Vegetables in Wisconsin," a series of five publications with different prices, is available from University of Wisconsin Cooperative Extension Publications, (608) 2623346.

"Organic Certification of Crop Production in Minnesota" is $\$ 3$ plus $\$ 2$ shipping from University of Minnesota Extension Service, Distribution Center, 1420 Eckles Ave. St. Paul, MN 55108; 1-800-876-8636.

"Northeast Aquaculture: Farming the Waters," a 30-minute video, \$10; "Facilities for Roadside Markets," 32 pages, $\$ 10.50$; and "Guide to Great Forestry and Natural Resources Publications," a publication of 1,300 resources, $\$ 13.50$, are all available from Northeast Regional Agricultural Engineering Service, (607) 255-7654; e-mail nraes@cornell.edu

'Eco-Labels: The Key to Consumer Support" is $\$ 35$ from The Food Alliance, 1829 NE Alberta St., \#5, Portland, OR 97211; (503) 493-1066; e-mail tfa@thefoodalliance.org

California Federation of Certified Farmers' Markets lists 350 farmers' markets on the Internet at http://farmersmarket.ucdavis.edu; for information, contact Susan McCue, UC Small Farm Center, (530) 752-7849; e-mail semccue@ucdavis.edu

"Urban Agriculture: An Abbreviated List of References and Resource Guide" is available from Alternative Farming Systems Information Center, National Agricultural Library, ARS, USDA, 10301 Baltimore Ave.
\#304, Beltsville, MD 20705; (301) 504-6559; or on the Internet at http://www.nal.usda.gov/afsic

"The Future Agenda for Organic Trade," proceedings of the 1997 Organic Trade Conference, are $\$ 30$ from IFOAM, fax +49-6853-30110, or e-mail ifoam@T-Online.de

"Sustaining Profits and Forests" is $\$ 10$ from Island Press, Box 7, Dept. 2AU, Covelo, CA 95428; 1-800-828-1302; e-mail ipwest@igc.apc.org; on the Internet, http://www.islandpress.org

Four films: "An Introduction to Ecological Economics" (\$25); "Investing in Natural Capital” (\$29.95); “Conversation for a Sustainable Society" (\$25); and "Costa Rica Counts the Future" (\$39.95) are available from Grieslinger Films, 7300 Old Mill Road, Gates Mills, OH 44040; 1-800-872-4456; email Prgfilms@ix.netcom.com

"Time for a Change: Pesticides and Wine Grapes in Sonoma and Napa Counties, California" is $\$ 5$ plus $\$ 2$ shipping from Californians for Alternatives to Toxics, P.O. Box 1195, Arcata, CA 95518; (707) 822-8497; email cats@igc.org 